\title{
Comparative Local Case Study of Coniferous Forest Litter of the "Pinus halepensis Mill" in Arid and Semi-arid Areas of Western Algeria
}

\author{
Mohamed ZouidI ${ }^{\mathrm{a}, \mathrm{b}^{*}}-$ Amine Habib BORSALI $^{\mathrm{a}, \mathrm{b}}-$ Ayoub ALLAM $^{\mathrm{a}, \mathrm{b}}-$ \\ Raphael GROS $^{\mathrm{c}}-$ Catherine REBUFA $^{\mathrm{c}}$ - Anne-Marie Farnet DA SILVA \\ ${ }^{a}$ Department of Biology, University «Dr Moulay Tahar» 20000 Saïda, Algeria \\ ${ }^{\mathrm{b}}$ Laboratory "Water Resources and Environment" 20000 Saïda, Algeria \\ c Aix Marseille University, CNRS, IRD, Avignon University, IMBE UMR 7263, Marseille, France
}

\begin{abstract}
Forest tree species produce litter, which is the plant/soil interface that ensures the maintenance of soil fertility whose properties depend on the botanical species considered. The differences of properties are marked in the nature of the decomposition processes and the forms of humus which result from it. In this study, the physicochemical characteristics and biological activity of litter were compared in coniferous plots located in the semi-arid and the arid zones of western Algeria. The objective of this work was to characterize and compare the physical-chemical properties and microbiological characteristics of softwood forest litter in the semi-arid and arid areas of western Algeria. We analyzed the properties of 50 samples of Aleppo pine litter collected from five stations in each zone. Analysis results show a highly significant difference $(\mathrm{p}<0.05)$ in the physical-chemical properties between the semi-arid and arid zone: humidity $(20.7 \%-6.51 \%), \mathrm{pH}(5.98-6.14)$, conductivity $(0.42 \mathrm{mS} / \mathrm{cm}-0.65 \mathrm{mS} / \mathrm{cm})$, carbon $(45.74 \%-73.42 \%)$, nitrogen $(1.17 \%-0.86 \%)$ and $\mathrm{C} / \mathrm{N}$ ratio (37.47 - 73.42). A comparison of the mean of microbial biomass and their efficacy reveals what is homogeneous in both zones, with a small difference in basal respiration.

The heterogeneity of these results indicates that such observations still need to be made in other forests of the Algerian territory in order to better understand the functioning of forest ecosystems and the effect of climate on these compartments, especially soil.
\end{abstract}

decomposition / physicochemical properties / biological parameters /aridity / Aleppo pine

Kivonat - Az Aleppó-fenyő erdei avarjának összehasonlító vizsgálata Nyugat-Algéria száraz és félszáraz területein. Az erdővel borított területek talaj/növény rendszerében a talaj termékenységének fenntartását az erdei fafajok avarprodukciója biztosítja. A termőrétegképződés folyamatának tulajdonságai jelentősen függenek a fajfajösszetételtől, ebből eredően pedig különbségek jellemzik a bomlási folyamatokat és a keletkező humuszformákat. Jelen tanulmányban avarminták fizikai-kémiai tulajdonságait, valamint a bennük lezajló biológiai aktivitást hasonlítottuk össze nyugat-Algéria félszáraz és száraz övezeteiben fekvő tülevelü állományokban. A vizsgálat fö célja a kutatási területekről származó fenyőavar fizikai-kémiai és mikrobiológiai tulajdonságainak jellemzése és összehasonlítása volt. A kutatás során 50 Aleppó-fenyő avarminta tulajdonságait vizsgáltuk minden mintaterületről 5 mintát gyüjtve. Az eredmények szignifikáns $(\mathrm{p}<0,05)$ eltérést mutatnak a félszáraz és száraz övezetek mintáinak fizikai-kémiai tulajdonságai között: nedvességtartalom $(20,7 \%-6,51 \%)$,

\footnotetext{
* Corresponding author: zoiudibiologie20@gmail.com; 02 City Sahraoui AEK Youb, DZA-20 000 SAÏDA, Algeria
} 
pH $(5,98$ - 6,14), vezetőképesség $(0,42 \mathrm{mS} / \mathrm{cm}-0,65 \mathrm{mS} / \mathrm{cm})$, szén $(45,74 \%$ - 73,42\%), nitrogén $(1,17 \%-0,86 \%)$ és $\mathrm{C} / \mathrm{N}$ arány $(37,47-73,42)$. A mikrobiális biomassza átlagának és hatékonyságának összehasonlítása azt mutatja, hogy mindkét zónában homogének a folyamatok, csak kis különbség van az alaplégzésben. Az eredmények alapján Algéria egyéb erdeiben is vizsgálatokat kell végezni az erdei ökoszisztémák müködésének és az éghajlati hatások jobb megértése érdekében, különösen a talajra nézve.

\section{lebontás / fizikai-kémiai tulajdonságok / biológiai aktivitás / szárazság / Aleppó-fenyő}

\section{INTRODUCTION}

Considering the bioclimatic criteria, Algeria includes all the Mediterranean bioclimates from moist to dry. Forest formations are found on virtually all bioclimatic stages. This allows the presence of a great diversity of biotopes occupied by an important floristic richness especially in the forest ecosystems that are found at almost all stages of bioclimatics. Today the Forestry Directorate-General (DGF 2018) estimates this forest heritage at 4.1 million ha, of which 1.420.000 ha consists of forests, 2.410.000 ha of Maquis shrubland, and 280.000 ha of young reforestation. The main tree species are Aleppo pine (Pinus halepensis) (69\%) and cork oak (Quercus suber) (21\%). In smaller areas, cedar (Cedrus satlantica), maritime pine (Pinus pinaster), oak species (Quercus ilex, Q. faginea, $Q$. suberet $Q$. afares), and eucalyptus are predominant (DGF 2018).

The Aleppo pine forests are mostly present at the semi-arid level, content with $350 \mathrm{~mm}$ of annual precipitation, and adapting to any type of soil. Occupying the highest area in Algeria, they are essentially confined to the east and west of the country. The areas of Aleppo pine are found on the coastline, the Tell, the Saharan Atlas, and the Aures Nememcha. In Algeria, the forest has social and scientific functions and, to a lesser degree, an economic function especially in relation to cork oak (Quercus suber) (Louni 1994). Algeria is characterized by very diverse and fragile forest ecosystems, incumbent on its geographical position and the significant variations of its climate.

In Algeria, conifers include the majority of forest and pre-forest formations. These are very important economically and ecologically, particularly through their role of protecting the soil from the processes of desertification and erosion, which are very dynamic in the semiarid and arid regions (Benabadji et al. 2007). These areas are among the most fragile ecosystems in the world due to recurrent droughts and the growing overexploitation of scarce resources. Arid and semi-arid areas occupy about one-third of the earth's land surface and account for roughly one billion human inhabitants, who are often among the poorest in the world (Malagnoux et al. 2007). Forests, trees, and herbaceous plants are essential components of arid-zone ecosystems. At the level of these semi-arid and arid areas, vegetation is continually struggling against harsh climatic factors, and nutrient-poor soil and organic matter (Borsali 2013).

Among various factors, forest/soil relationships can be addressed through the impact of litter on fertility (Dupuy 1998). Litter is the superficial layer that covers the soil. It constitutes the vegetal mass from the leaves (70 to 94\%), branches, and stems and forms all the organic matter (Rapp 1969, Mangenot 1980). Many factors may be involved in litter decomposition; physicochemical properties play an especially important role (Lossaint 1959). Indeed, litter plays an important role in soil protection, the storage of mineral elements, and the restitution of these minerals to the soil. The disappearance or destruction of litter is accompanied by a sudden fall in the stock of available mineral elements, which may be a limiting factor for plant growth (Dupuy 1998). The suppression or decrease of protective layers represented by litter and vegetation after a fire subjects the ground to direct sunlight and raises its general 
temperature (Raison et al. 1986) because litter plays the role of a sponge that protects the ground and keeps it moist (Faurie 2011).

Through temperature and humidity, the climate directly influences the decomposition of plant debris; however, the climate can also affect the physicochemical and biological properties of litter through its influence on plant community composition and litter quality (Lavelle et al. 1993, Aerts 2006, Pérez et al. 2007). Our objective was to characterize and compare the physical-chemical and microbiological properties of softwood forest litter in semi-arid and arid areas of western Algeria to see if the arid gradient has an effect on these characteristics in order to better anticipate the future of litter in the semi-arid zone due to climate change. The sites were chosen to cover the panel of pedoclimatic conditions corresponding to the semi-arid and arid climates of the western Algeria.

\section{MATERIALS AND METHODS}

\subsection{Study areas}

\subsubsection{Semi-arid area}

The Jebel Sid Ahmed Zeggai forest is located $4.5 \mathrm{~km}$ west of Saida province; it is part of the mountains of Saida, which are the eastern extension of the mountains of Dhaya, which belong to the Atlas Tellian (Figure 1). This forest covers an area of 2232 hectares on a limestone brown soil dominated by $90 \%$ Aleppo pine. Other plant species present are: are lentisk (Pistacia lentiscus L), cade juniper (Juniperus oxycedrus), evergreen oak (Quercus ilex), and esparto grass (Stipa tenacissima). This forest is extremely dense (2000 plant ha $\left.{ }^{-1}\right)$ and has significant regeneration. Aleppo pine has an average age of 50 years with an average height of 6 to $8 \mathrm{~m}$. From a climatic point of view, the forest benefits from a semi-arid climate $\left(\mathrm{T} \min =3{ }^{\circ} \mathrm{C}\right.$, $\mathrm{P}=344.6 \mathrm{~mm}$ ) located on superior stage of the Mediterranean vegetation $\left(\mathrm{T} \min >3{ }^{\circ} \mathrm{C}\right.$, $200<\mathrm{P}<400 \mathrm{~mm}$ ); the seasonal regime of the zone is of the HAPE type (Winter, Autumn, Spring, Summer) and has 6 months of drought (Zouidi et al. 2019).

\subsubsection{Arid area}

The Jebel Antar Forest is located in the commune of Mecheria in the east of Naama province (Figure 1). This forest is a piedmont area of Jebel that plays a protective role against the desertification of the area. It is a mass afforestation with an area of 1000 ha on a calcimagnesic soils. Aleppo pine is used as the main species at a rate of $95 \%$ with a density of 1600 plant/ha. Cepressus (Cupressus), betoum (Pistacia antlantica), white retem (Retama raetam), esparto grass (Stipa tenacissima), and white wormwood (Artemisia herba-alba) are also found in this forest. Today, Aleppo pine trees have an average height of between 3 and $5 \mathrm{~m}$. The area has recently encountered several factors of degradation due to desertification and urbanization with the consequence of a radical transformation of the affected plant formations. The forest benefits from an arid climate $\left(\mathrm{T} \min =2{ }^{\circ} \mathrm{C}, \mathrm{P}=203.5 \mathrm{~mm}\right)$ located on a superior stage of the Mediterranean vegetation ( $\mathrm{T} \min >2{ }^{\circ} \mathrm{C}, 100<\mathrm{P}<300 \mathrm{~mm}$ ). The seasonal regime is type APHE (autumn, spring, winter, summer) with 8 months of drought (Zouidi et al. 2018). 

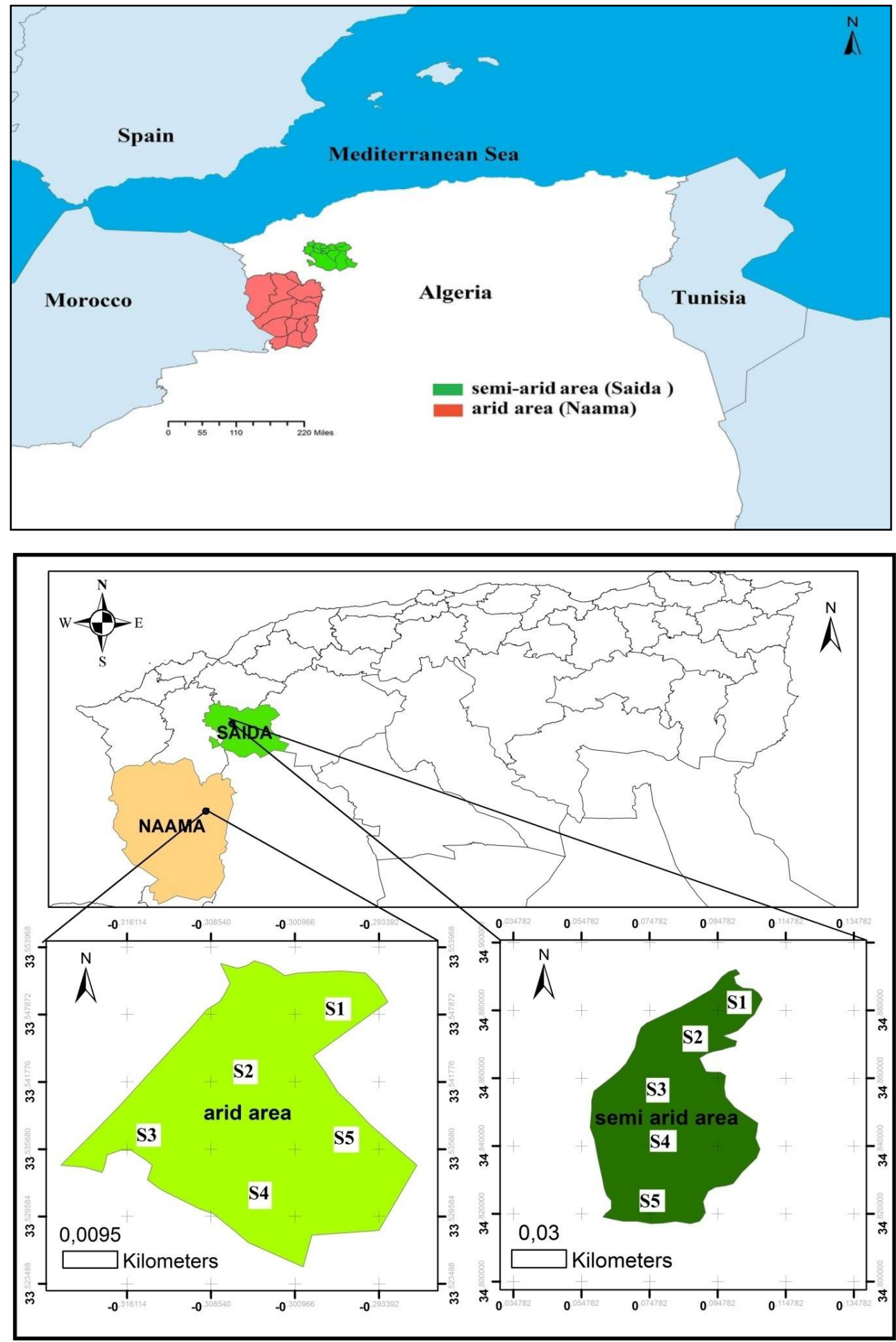

Figure 1. Geographical situations of study areas

\subsection{Litter Sampling}

Five sampling stations were selected for each zone (Table 1). Five samples were randomly collected at each station. All stations are located at altitudes between 970 and $1280 \mathrm{~m}$ with a similar exposure $(\mathrm{N})$. Samples of approximately $1 \mathrm{~kg}$ of litter (OL horizon) were collected under the canopy of Pinus halepensis. Mill. in March 2016. Each sample was sorted manually to remove any shellfish shells, pebbles, or twigs. 
Table 1. Geographical and characterizations of the study stations

\begin{tabular}{lcccc}
\hline Areas & Station & Altitude $(\mathrm{m})$ & Latitude & Longitude \\
\hline \multirow{5}{*}{ semi-arid area } & S 01 & 975 & $34^{\circ} 52^{\prime} 13.7^{\prime \prime} \mathrm{N}$ & $00^{\circ} 05^{\prime} 09.5^{\prime \prime} \mathrm{E}$ \\
& $\mathrm{S} 02$ & 1067 & $34^{\circ} 51^{\prime} 22.3^{\prime \prime} \mathrm{N}$ & $00^{\circ} 04^{\prime} 40.9^{\prime \prime} \mathrm{E}$ \\
& $\mathrm{S} 03$ & 1146 & $34^{\circ} 50^{\prime} 29.5^{\prime \prime} \mathrm{N}$ & $00^{\circ} 04^{\prime} 57.6^{\prime \prime} \mathrm{E}$ \\
& $\mathrm{S} 04$ & 1160 & $34^{\circ} 49^{\prime} 31.8^{\prime \prime} \mathrm{N}$ & $00^{\circ} 05^{\prime} 22.6^{\prime \prime} \mathrm{E}$ \\
& $\mathrm{S} \mathrm{05}$ & 1081 & $34^{\circ} 49^{\prime} 23.7^{\prime \prime} \mathrm{N}$ & $00^{\circ} 04^{\prime} 33.8^{\prime \prime} \mathrm{E}$ \\
\hline \multirow{5}{*}{ arid area } & $\mathrm{S} \mathrm{01}$ & 1080 & $33^{\circ} 32^{\prime} 02.3^{\prime \prime} \mathrm{N}$ & $00^{\circ} 19^{\prime} 13.1^{\prime \prime} \mathrm{W}$ \\
& $\mathrm{S} \mathrm{02}$ & 1140 & $33^{\circ} 32^{\prime} 23.7^{\prime \prime} \mathrm{N}$ & $00^{\circ} 18^{\prime} 25.1^{\prime \prime} \mathrm{W}$ \\
& $\mathrm{S} \mathrm{03}$ & 1119 & $33^{\circ} 32^{\prime} 51.6^{\prime \prime} \mathrm{N}$ & $00^{\circ} 17^{\prime} 55.0^{\prime \prime} \mathrm{W}$ \\
& $\mathrm{S} \mathrm{04}$ & 1085 & $33^{\circ} 31^{\prime} 52.7^{\prime \prime} \mathrm{N}$ & $00^{\circ} 17^{\prime} 55.3^{\prime \prime} \mathrm{W}$ \\
& $\mathrm{S} \mathrm{05}$ & 1108 & $33^{\circ} 31^{\prime} 52.7^{\prime \prime} \mathrm{N}$ & $00^{\circ} 18^{\prime} 25.6^{\prime \prime} \mathrm{W}$ \\
\hline
\end{tabular}

\subsection{Physicochemical Analyses}

Litter water content was determined by measuring fresh weights and weights after ovendrying $\left(80^{\circ} \mathrm{C}\right)$ for $24 \mathrm{~h}$ (Alarcón-Gutiérrez 2007). The $\mathrm{pH}$ and conductivity of the samples were measured on a litter suspension obtained by mixing $5 \mathrm{~g}$ of litter with $100 \mathrm{~mL}$ of distilled water. The measurement was carried out $2 \mathrm{~h}$ after using a $\mathrm{pH}$ meter (Métrohm, Herisau, Switzerland) (Alarcón-Gutiérrez 2007). Total organic carbon (COT) and total nitrogen (TN) were measured as follows: kiln-dried initial litter subsamples and each microcosm litter were sprayed in a ceramic mortar and analyzed by combustion in an analyzer Elemental, FlashEA 1112, Thermo Fisher; the calculated $\mathrm{C} / \mathrm{N}$ ratio then presents a chemical character that may show the decay rate of plant debris (Gloaguen -Touffet 1982).

\subsection{Biological analysis}

Basal respiration ( $\mu \mathrm{g} \mathrm{C}-\mathrm{CO}_{2} / \mathrm{g}$ dry litter) was measured according to the protocol described by Anderson and Domsch (1978) to assess the physiological state of the microbial communities of litter; 3 grams (dry equivalent) of fresh litter stored at $4{ }^{\circ} \mathrm{C}$ were weighed in a glass vial $(117 \mathrm{ml})$. The vials were closed with a hermetically sealed plug immediately after the replacement (4 minutes) of their internal atmosphere via a stable $\mathrm{CO}_{2}$ concentration atmosphere, and incubated 4 hours at $25^{\circ} \mathrm{C}$. After incubation, an aliquot of atmosphere of the vial $(1 \mathrm{ml})$ was injected using a syringe into a gas chromatograph (Chrompack CHROM 3 CP 9001). The chromatograph was equipped with a TCD detector and a filled column (Porapack) in which helium circulates at a flux of $60 \mathrm{~mL} / \mathrm{h}$. The values obtained were adjusted to $22^{\circ} \mathrm{C}$ according to the law of the gases perfect at $\mathrm{Q} 10=2$. Ambient $\mathrm{CO}_{2}$ concentrations were subtracted from the $\mathrm{CO}_{2}$ concentrations measured after incubation to obtain the amount of $\mathrm{CO}_{2}$ produced by the heterotrophic microorganisms contained in the sample. Microbial biomass was estimated by the glucose-induced respiration method (Anderson - Domsch, 1978). A mixture of talc and glucose (1 $000 \mu \mathrm{g}$ carbon/g of litter) was added to the three grams (dry equivalent) of litter. An incubation of 100 minutes was performed to achieve a maximum rate of induced respiration. The vials were closed with an airtight stopper immediately after the replacement (4 minutes) of their internal atmosphere by an atmosphere of stable $\mathrm{CO}_{2}$ concentration, and then incubated for 90 minutes at $22^{\circ} \mathrm{C}$. The $\mathrm{CO}_{2}$ concentration of the vials was analyzed with gas chromatography and corrected in the same way as previously described for basal respiration. Induced respiration rates were converted to microbial biomass values using the equation given by Beare et al. (1990). The metabolic quotient $\left(\mathrm{qCO}_{2}\right)$ was calculated as the ratio of basal respiration/microbial biomass to Anderson and Domsch (1985). 


\subsection{Data analysis}

The student $t$-test was used to compare the results of the physicochemical and microbiological properties of litter between the semi-arid and the arid areas using Sigmaplot 14 software.

\section{RESULTS}

\subsection{Physicocemical characteristics}

The evaluation of litter quantities of Aleppo pine litter taken from one square meter shows a good production of litter with high moisture in the semi-arid zone $\left(1493 \mathrm{gr} / \mathrm{m}^{2} ; 20.70 \%\right)$ compared to the litter in our arid zone, which presents quantities $\left(906.4 \mathrm{gr} / \mathrm{m}^{2}\right)$ with low moisture $(6.51 \%)$. The comparison of the averages reveals this difference is significantly high between the two zones $(\mathrm{p}<0.001)$. Conductivity and $\mathrm{pH}$ are elevated in the arid zone $(6.14$ for the $\mathrm{pH}$ and $0.65 \mathrm{mS} / \mathrm{cm}$ for the conductivity). The $\mathrm{pH}$ is low acid ( $\mathrm{pH}$ greater than 5) in our semi-arid zone with a low conductivity $(0.42 \mathrm{mS} / \mathrm{cm})$ and presents a significant difference between the two zones $(\mathrm{p}<0.001)$. On the basis of the results, a carbon concentration and a high $\mathrm{C} / \mathrm{N}$ ratio were recorded in the arid zone ( 73 for the $\mathrm{C} / \mathrm{N}$ ratio; $73.42 \%$ for the carbon) in contrast to the concentration of nitrogen, which presents a significant average in our semi-arid zone $(1.17 \%)$ more than the arid zone $(0.86 \%)$. The statistical study based on the comparison of the means (student's t test) shows a highly significant difference $(\mathrm{P}<0.001)$ of these parameters (Figure 2).

\subsection{Microbial properties of litters}

The microbial parameter averages of litters are recorded in table 02. Based on the comparison of biological parameter averages of litter, we recorded a high basal respiration in the semi-arid zone $\left(97.78 \mu \mathrm{g}\right.$ de $\left.\mathrm{C}-\mathrm{CO}_{2} / \mathrm{h} / \mathrm{g}\right)$ compared to the arid zone, which presents an average of 85.42 $\mu \mathrm{g}$ of $\mathrm{C}-\mathrm{CO}_{2} / \mathrm{h} / \mathrm{g}$. Statistical analysis of the results shows a notably small difference $(\mathrm{t}=2.14$; $\mathrm{p}<0.05)$ of this microbial basal respiration (BR) between these two zones. It should be noted that the average of microbial biomass $(\mathrm{BM})$ and metabolic quotient $\left(\mathrm{qCO}_{2}\right)$ are high in our semi-arid zone $\left(\mathrm{BM}-4.31 \mu \mathrm{g}\right.$ of carbon microbial $/ \mathrm{g} ; \mathrm{qCO}_{2}-23.67 \mu \mathrm{g}$ of $\mathrm{C}-\mathrm{CO}_{2} / \mathrm{h} / \mathrm{g}$ ). However, the bacterial biomass and the metabolic quotient did not show any noteworthy difference between the two zones ( $p>0.05)$.

Table 2. Microbiological properties of forest litter in arid and semi-arid areas.

\begin{tabular}{lccc}
\hline Microbial analysis & Student test- $t$ & Semi-arid area & Arid area \\
\hline $\begin{array}{l}\text { Basal respiration at } 22^{\circ} \mathrm{C} \\
\left(\mu \mathrm{g} \text { of } \mathrm{C}-\mathrm{CO}_{2} / \mathrm{h} / \mathrm{g}\right)\end{array}$ & $2.14^{*}$ & $97.78 \pm 17.39$ & $85.42 \pm 22.98$ \\
$\begin{array}{l}\text { Microbial biomass } \\
(\mu \mathrm{g} \text { of Carbon microbial/g) }\end{array}$ & $1.73 \mathrm{~ns}$ & $4.31 \pm 0.90$ & $3.94 \pm 0.54$ \\
$\begin{array}{l}\text { Metabolic quotient }(\mathrm{qCO} 2) \\
(\mu \mathrm{g} \text { of } \mathrm{C}-\mathrm{CO} 2 / \mathrm{h} / \mathrm{g})\end{array}$ & $0.753 \mathrm{~ns}$ & $23.67 \pm 6.51$ & $22.17 \pm 7.57$ \\
\hline
\end{tabular}

This table records the average values \pm deviation; Microbial properties of soils; the $p$ value of independent test is presented with its threshold of significance $(*: p<0.05 ; * *: p<0.01 ; * * *: p<0.001$; ns: not significant). 

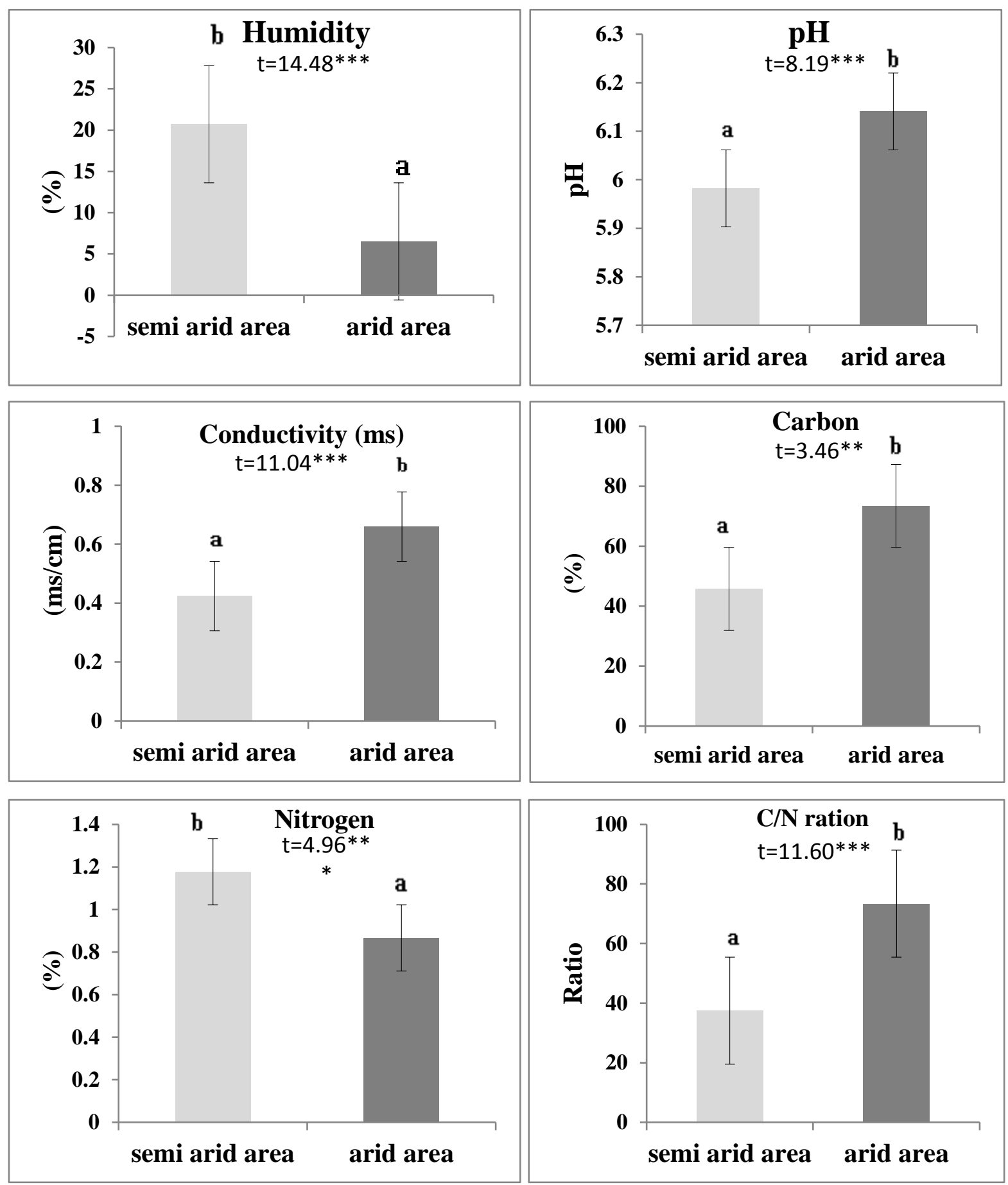

Figure 2. Physicochemical parameters of litter in semi-arid and arid areas. Averages \pm standard deviations. The $t$-value of the Student's test is presented with its significance threshold $(*: p<0.05, * *: p<0.01, * * *: p<0.001$, ns: not significant)

\section{DISCUSSION}

Forest litter is mainly composed of softwood leaves, needles, and dead wood. It forms a source of energy and essential elements for the metabolism of microbial communities. Our study reveals there is an effect of the arid gradient on the production of pinus halepensis litter, which is more important in the semi-arid zone compared to the arid zone. This is certainly due 
to forest density as well as climatic and edaphic conditions specific to each area. Several scientists have shown that litter production is controlled by climatic and edaphic factors that regulate production and forest stand density (Puig - Delobelle 1988, Mutabesha 2009). Litter in arid forests is susceptible to winds, and according to Kumada et al. (2008), it is natural that this weather effect removes a significant amount of litter.

The work presented in this research concerns the quality of litter in two areas on two different bioclimatic stages (arid and semi-arid). The moisture measurements highlight the footprint of the climatic stage on each zone. In fact, litter in the semi-arid zone has a more significant proportion of moisture than litter in the arid zone, which indicates that the wilted leaves of Pinus halepensis retain more water in the semi-arid zone. Air and rainfall are more important in this area when it comes to soil moisture $(344 \mathrm{~mm} / \mathrm{year})$ than it is in the arid area where there is less rain $(203 \mathrm{~mm} /$ year) and, therefore, less water in the soil and litter (Zouidi et al. 2018, Zouidi et al. 2019). It should also be stressed that water evaporation of leaves in the semi-arid zone is low as it is in the arid zone where temperatures and periods of drought are longer and more pronounced. In addition, the low density of species trees and herbaceous species are non-existent in the arid zone, which facilitates the loss of water from the litter and soil. Consequently, the water content of the litter and the dead plants depend solely on physical phenomena such as exchange by capillarity with the soil and in equilibrium with the moisture content (in vapor form) of the atmosphere located in immediate contact with the litter (Trabaud 1976). High temperatures with reduced plant cover in the arid zone also reduce soil moisture by increasing evaporation (soil and litter) and perspiration (Tardif 2013).

The $\mathrm{pH}$ of litter in both the semi-arid zone (5.98) and the arid zone (6.14) are low in acid $(\mathrm{pH}>5)$. Softwoods, and especially pine, are considered acidifying species (Gobat et al. 2003, Lagace 2009); in fact, the litter acidifies during decomposition and its $\mathrm{pH}$ gradually rises to 6 after 3 months (Lossaint 1959). The $\mathrm{pH}$ is more acidic in the semi-arid zone because there is less leaching that will limit the pluviolessivats loaded with phenols (which can deproton and therefore generate a higher acidity) (Bernhard-Reversat 1972). On the other hand, this is also probably due to the higher $\mathrm{CaCO}_{3}$ content in the arid zone, which acts like a 'tampon' and, therefore, causes a small increase the $\mathrm{pH}$ (Zouidi et al. 2018). Litter in the arid zone may remain saline compared to litter in semi-arid areas. This result is probably related to the nature of soil and the presence of minerals in soils in this arid zone (Zouidi et al. 2018). The difference in carbon levels between the two zones can be explained in the following manner: the high percentage in the arid zone can be explained by the pedoclimatic variation between the two study areas, which influences the significant photosynthetic activity of the conifers, especially in the presence of solar radiation in the arid zone that lasts all year as shown by Puig and Delobelle (1988). Changes in carbon levels, therefore, reflect the climatic or edaphic variations of an annual cycle with a lag of a few months. Forest litter fallout and decomposition are key processes in the formation of carbon (C) and nutrient cycling in terrestrial ecosystems. These processes determine the amount of carbon stored in the humus (Berg et al. 2001, Sabine et al. 2014). Carbon stocks will increase if litter production (carbon input) increases. With regard to litter production, it is closely related to the rainfall regime. The lack of rainfall in the arid zone ( 8 months dry) is accompanied by falling leaves, which translates into increased litter production (Paul - Clark 1996, Dupuy 1998). This also explains the significant amount of carbon in the arid zone, which has a seasonal rainfall regime that is less than that of the semi-arid zone. This causes pine trees to shed their needles and increases litter production. The accumulation of organic carbon in the humus of the closed conifer formation can be explained by the quality of the litter composed of recalcitrant materials to the microbial decomposition such as tannins and polyphenols (Berg 2000, Prescott et al. 2000). Nitrogen levels remain low, especially in arid zones. This can be explained by the very slow decomposition of the Aleppo pine litter; indeed, several studies have confirmed that 
decomposition is influenced by the initial concentrations of mineral nitrogen (Aerts 1997, Kaspari et al. 2008, Wieder et al. 2009) and total litter nitrogen, which decreases with decomposition (Gloaguen - Touffet 1982, Qasemian et al. 2012). According to Salleles (2014), the source of nitrogen for plants in low-input (unfertilized) ecosystems such as arid zones is mainly derived from litter decomposition and the mineralization of soil organic matter. As a result, litter plays an essential role in the recycling of nitrogen in the forest ecosystem (Salleles 2014). When litter is subjected to favorable climatic conditions (temperature and humidity), it has a high initial nitrogen content (Kurz-Besson 2000). This is one of the key factors that regulate the decay rate of plant debris, as pointed out recently (Taylor et al. 1989). Conifers are characterized by acidifying litter which, due to their composition, cause a slowing of the biodegradation of humification with a $\mathrm{C} / \mathrm{N}$ ratio generally greater than 50 (Duchaufour, 1980). The $\mathrm{C} / \mathrm{N}$ ratio in the semi-arid zone translates into the capacity of a litter to be decomposed more or less rapidly in the arid zone. This shows a very slow decay. This report is only a general indication of the potential of litter to decay (Taylor et al. 1989). A strong $\mathrm{C} / \mathrm{N}$ ratio of the initial litter was correlated with a low rate of decay and increased with the age of the needles in place, corresponding to nitrogen depletion and lignin enrichment (Gloaguen - Touffet 1982, Lagacé 2009).

The results showed that microbial biomass remains homogeneous and low in both the arid and semi-arid zones as a result of lack of water and high temperatures. As some authors have reported in their work (Sabaté et al. 2002, Papa et al. 2008), the most important factors affecting soil microbial biomass are precipitation and temperature. In addition, studies on forest ecosystems have shown significant decreases in fungal and bacterial biomass during drought periods (Krivtsov et al. 2006, Borsali et al. 2017). Salinity is a factor influencing the activities of microorganisms, particularly in arid and semi-arid areas (Toberman et al. 2008). Basal respiration remains weakly variable between the two zones and depends on water availability, temperature, and biochemical composition of litters such as lignin, cellulose, hemicellulose, and $\mathrm{C} / \mathrm{N}$ ratio (Arunachalam et al. 1998).

\section{CONCLUSION}

Forest litter is the plant-like interface in the forest that protects the soil and ensures that fertility is maintained through the production of nutrients. The aim of this study was to demonstrate the differences between litters in semi-arid and arid areas and to determine any imprint of exposure to bioclimatic stages on the physicochemical and biological properties of resin litter. The results showed a significant difference in all physicochemical parameters $(\mathrm{p}<0.05)$ and particularly in moisture where a $14.19 \%$ difference between the two areas was recorded. The differences for carbon and nitrogen, both of which promote decomposition and ensure the life of decomposing organisms, were $27.68 \%$ and $0.49 \%$, respectively. The $\mathrm{pH}$ of the two semi-arid and arid zones shows that acidifying litters are mull or mild humus $(\mathrm{pH}>5)$; this acidity is a character of conifers and in particular Aleppo pine. The decrease in the moisture content of the arid forest litter $(6.51 \%)$ caused an increase in carbon $(73.42 \%)$ content and, consequently, the elevation of the $\mathrm{C} / \mathrm{N}$ ratio $(73 \%)$ and the slow decay of the litter. Litter degradation in the arid zone is slower than in the semi-arid zone. This is due to the pedoclimatic factors of the arid zone (mother rock nature, precipitation erosion, drought, and salinity). The forests dominated by Aleppo pine from both zones produce poor quality litters that are difficult to degrade. In these zones litter possess low activity and low microbial biomass, with an average of $4.12 \mu \mathrm{g}$ of carbon microbial/ $\mathrm{g}$. 
Acknowledgements: We would like to thank the Mediterranean Institute of Biodiversity and Marine and Continental Ecology, University of Aix-Marseille, France, for the chemical and biological analyses of forest litter.

\section{REFERENCES}

AERTS, R. (1997): Climate, leaf litter chemistry and leaf litter decomposition in terrestrial ecosystems: a triangular relationship. Oikos 79: 439-449. http://doi.org/10.2307/3546886

AERTS, R. (2006): The freezer defrosting: global warming and litter decomposition rates in cold biomes. Journal of Ecology 94 (4): 713-724. https://doi.org/10.1111/j.1365-2745.2006.01142.x

ALARCÓN-GUTIÉRREZ, E. (2007): Influence de facteurs abiotiques sur la régulation des paramètres microbiens impliqués dans la dégradation de la matière organique d'une litière forestière méditerranéenne [Influence of abiotic factors on the regulation of microbial parameters involved in the degradation of organic matter in a Mediterranean forest litter] Doctoral thesis, AixMarseille, France, 227p. (in French)

ANDERSON, J.P.E. - DOMSCH, K.H. (1978): A physiologi cal method for the quantitative measurement of microbial biomass in soils. Soil Biology Biochemistry Journal 10: 215-221. https://doi.org/10.1016/0038-0717(78)90099-8

ANDERSON, T. H. - DOMSCH, K. H. (1985): Maintenance carbon requirements of activelymetabolizing microbial populations under in situ conditions. Soil Biology and Biochemistry 17 (2): 197-203. https://doi.org/10.1016/0038-0717(85)90115-4

Arunachalam, A. - Maithani, K. - PANDEy, H. N. - TRipathi, R. S. (1998). Leaf litter decomposition and nutrient mineralization patterns in regrowing stands of a humid subtropical forest after tree cutting. Forest Ecology and Management 109 (1-3): 151-161. https://doi.org/10.1016/S0378-1127(98)00240-0

Beare, M.H. - Neely, C.L. - Coleman, D.C. - Hargrove, W.L. (1990): A substrate-induced respiration (SIR) method for measurement of fungal and bacterial biomass on plant residues. Soil Biology Biochemistry Journal 22: 585-594. https://doi.org/10.1016/0038-0717(90)90002-H

Benabadji, N. - Benmansour, D. - BouazzA, M. (2007): La flore des monts d'Ain Fezza dans l'ouest algérien, biodiversité et dynamique [The flora of the mountains of Ain Fezza in western Algeria, biodiversity and dynamics] Science \& Technology C, 26: 47-59. (in French)

BERG, B. (2000): Litter decomposition and organic matter turnover in northern forest soils. Forest Ecology and Management 133: 13-22. https://doi.org/10.1016/S0378-1127(99)00294-7

Berg, B. - MCClaugherty, C. - SANTO, A. V. D. - JohnSON, D. (2001): Humus buildup in boreal forests: effects of litter fall and its N concentration. Canadian Journal of Forest Research 31 (6): 988-998. https://doi.org/10.1139/x01-031

BERNHARD REVERSAT, F. (1972): Décomposition de la litière de feuilles en forêt ombrophile de basse Cote-d'Ivoire [Decomposition of leaf litter in low Ivory Coast rainforest] Oecologie plant arum 7 (3): 279-300. (in French)

BORSALI, A.H. (2013): Contribution à l'évaluation de l'impacte des incendies sur les écosystèmes forestiers: cas de la forêt de Fénouane, wilaya de Saïda. (Algérie) [Contribution to the evaluation of the impact of fi res on forest ecosystems: case of Fénouane Forest, municipality of Ain El Hadjer, Saida Province (Algeria)]. Doctoral thesis, Aix-Marseille, France, 213 p. (in French)

Borsali, A.H. - Zouidi, M. - HACHEM, K. - GROS, R. - THEONESTE, H. (2017): Catabolic profiles of cultivable microbial communities in forest soils of western Algeria along a latitudinal gradient. Advanced Studies in Biology 9(4): 157-169. https://doi.org/10.12988/asb.2017.749

BouDY, P. (1955): Economie forestière nord-africaine [North African forest economy]. flight. 1, forest description of Algeria and Tunisia. Larose, Paris, 483 p. (in French)

DGF (General Directorate of Forestry). (2018): Annual report on the state of vegetation cover in Algeria. Patrimoine forestier national Available in https://www.dgf.org.dz/fr/structure/conservation-forets.

Duchaufour, P. (1970): Humification et Ecologie [Humification and Ecology] ORSTOM Séries Pédologie 8 (4): 381-390. (in French) 
DuCHAUfOUR, P. (1980): Écologie de l'humification et pédogénèse des sols forestiers [Ecology of humification and soil pedogenesis forest] In: P. Pesson (ed.), Forest Ecology News, Gauthier Villars Paris. 177-201. (in French)

DUPUY, B. (1998): Bases for African tropical rain forest silviculture, FORAFRI Series, Document 04, $328 \mathrm{p}$.

FAURIE, C. (2001): Ecologie: approche scientifique et pratique [Ecology: scientific and practical approach] $6^{\text {th }}$ Edition. Lavoisier. 450 p. (in French)

GloAguen, J.C. - ToufFET, J. (1982): Évolution du rapport C/N dans les feuilles et au cours de la décomposition des litières sous climat atlantique. Le hêtre et quelques conifers [Evolution of the $\mathrm{C} / \mathrm{N}$ ratio in the leaves and during litter decomposition under Atlantic climate. Beech and some conifers] Annals of Forest Science 39 (3): 219-230. (in French)

GobAt, J.M - ARAGNO, M. - MATTHEY, W. (2003): The living soil. $2^{\text {nd }}$ edition. rev. and increase Coll. "Managing the environment", Lausanne: Polytechnic and University Press, 568p.

KASPARI, M. - GARCiA, M. N. - HARMS, K. E. - SANTANA, M. - Wright, S. J. - YAVITT, J. B. (2008): Multiple nutrients limit litterfall and decomposition in a tropical forest. Ecology letters 11 (1): 35-43. https://doi.org/10.1111/j.1461-0248.2007.01124.x

Krivtsov, V. - Bezginova, T. - SAlmond, Liddell, K. - Garside, A. - Thompson, J. PAlfReyman, J.W. - StAines, H.R. - BRendleR, A. - GRIFfiths, B. - WATLing, R. (2006): Ecological interactions between fungi, other biota and forest litter composition in a unique Scottish woodland. Forestry 79 (2): 201-216. https://doi.org/10.1093/forestry/cpi066

KUMADA, S. - KAWANISHI, T. - HAYASHI, Y. - OGOMORI, K. - KOBAYASHI, Y. - TAKAHASHI, N. YAMADA, K. (2008): Litter carbon dynamics analysis in forests in an arid ecosystem with a model incorporating the physical removal of litter. Ecological modelling 215 (1-3): 190-199.

KurZ-Besson, C. (2000): Décomposition de litieres de pin (Pinus sylvestris, P. halepensis, et $P$. pinaster) dans un transect climatique européen: rôle de la qualité des litières et du climat [Decomposition of pine litter, Pinus sylvestris, P. halepensis and P. pinaster, in a European climatic transect: Role of litter quality and climate] Doctoral thesis, University Paris-Sud, France, 280 pp. (in French)

LAGACÉ, B.J. (2009): Caractérisation des stocks de carbone de 5 types de formations végétales dans un secteur du bassin versant de la rivière Eastmain, Baie James [Characterization of carbon stocks of 5 types of vegetation in a sector of the Eastmain River watershed, James Bay] University of Quebec , Montreal, 160p. (in French)

LaVelle, P. - Blanchart, E. - Martin, A. - Spain, A. - Toutain, F. - Barois, I. - Schaefer, R. (1993): A hierarchical model for decomposition in terrestrial ecosystems: application to soil of the humid tropics. Biotropica 25: 130-150. http://doi.org/10.2307/2389178

LOSSAINT, P. (1959): Etude expérimentale de la mobilisation du fer des sols sous l'influence des litières forestières [Experimental study of the mobilization of soil iron under the influence of forest litter] Agronomic Annals 10: 369-414. (in French)

LOUNI, D. (1994): Les forêts algériennes [Algerian forests] Mediterranean Forest 15: 59-63. (in French)

MalagnouX, M. - Sene, E.H. - Atzmon, N. (2007): Forests, trees and water in arid lands: a precarious balance. Unasylva 229 (FAO). 58: 24-29

MANGENOT, F. (1980): Les litières forestières, signification écologique et pédologique. [Forest litter: ecological and pedological significance] French forestry review 4: 339-355. https://doi.org/10.4267/2042/21417 (in French)

MUTABESHA, M. P. (2009): Importance de la couverture au sol dans la restauration des écosystèmes forestiers: cas de la Réserve de biosphère de Luki au Bas Congo [Importance of ground cover in the restoration of forest ecosystems: the case of the Luki biosphere reserve in lower Congo] Thesis in agronomic sciences, University of Kinshasa DRC (in French)

PAPA, S. - Pellegrino, A. - Fioretto, A. (2008): Microbial activity and quality changes during decomposition of Quercus ilex leaf litter in three Mediterranean woods. Applied Soil Ecology 40 (3): 401-410. https://doi.org/10.1016/j.apsoil.2008.06.013

Paul, E. A. - ClarK, F. E. (1996): Soil microbiology and biochemistry, Academic Press, San Diego, California, $340 \mathrm{p}$. 
Pérez, H. N. - Diaz, S. - Vendramini, F. - Gurvich, D. E. - Cingolani, A.M. - Giorgis, M. CABIDO, M. (2007): Direct and indirect effects of climate on decomposition in native ecosystems from central Argentina. Austral Ecology 32 (7): 749-757. https://doi.org/10.1111/j.1442-9993.2007.01759.x

PrescotT, C. E. - Blevins, L. L. - STALEY, C. L. (2000): Effects of clear-cutting on decomposition rates of litter and forest floor in forests of British Columbia. Canadian Journal of Forest Research, 30(11): 1751-1757. https://doi.org/10.1139/x00-102.

PUig, H. - Delobelle, J. P. (1988): Production de litière, nécromasse, apports minéraux au sol par la litière en forêt guyanaise [Production of litter, necromass, mineral inputs on the soil by the litter in the Guyanese forest] Ecology Review 43 (1): 3-22. (in French)

QASEMian, L. - Guiral, D. - Ziarelli, F. - VAN DANG, T. K. - FARNET, A. M. (2012): Effects of anthracene on microbial activities and organic matter decomposition in a Pinus halepensis litter from a Mediterranean coastal area. Soil Biology and Biochemistry 46: 148-154. https://doi.org/10.1016/j.soilbio.2011.12.002

RAISON, R. J. - WoOdS, P. V. - KHANNA, P. K. (1986). Decomposition and accumulation of litter after fire in sub-alpine eucalypt forests. Australian journal of ecology 11 (1): 9-19. https://doi.org/10.1111/j.1442-9993.1986.tb00913.x

RAPP, M. (1969): Production de litière et apport au sol d'éléments minéraux dans deux écosystèmes méditerranéens: la forêt de Quercus ilex et la garrigue de Quercus coccifera. [Litter production and supply of mineral elements to the soil in two Mediterranean ecosystems: the forest of Quercus ilex L. and the garrigue of Quercus coccifera L. ] Oecol. Plant 4 (4): 377-410. (in French)

SABATÉ, S. - GRACiAA, C.A. - SÁNCHEZ, A. (2002): Likely effects of climate change on growth of Quercus ilex, Pinus halepensis, Pinus pinaster, Pinus sylvestris and Fagus sylvatica forests in the Mediterranean region. Forest Ecology and Management 162: 23-37.

Sabine, C. L. - Heimann, M. - ARTAXo, P. - BakKer, D. C. - Chen, C. T. A. - Field, C. B. LANKAO, P. R. (2004): Current status and past trends of the global carbon cycle. Scope-scientific committee on problems of the environment international council of scientific unions, 62: 17-44.

SALLELES, J. (2014): Étude du devenir de l'azote dérivé des litières dans le sol et dans l'arbre sur le moyen terme dans les forêts de hêtres par traçage isotopique et modélisation [Study of the fate of nitrogen derived from litter in the soil and in the tree in the medium term in beech forests by isotopic tracing and modeling] Doctoral thesis, University of Lorraine . 220 p. (in French)

TARDIF, A. (2013): Prédiction des taux de décomposition des litières végétales par les traits fonctionnels agrégés [Prediction of plant litter decomposition rates by aggregated functional traits] Doctoral thesis. University of Sherbrooke and Blaise Pascal University - Clermont-Ferrand II doctoral school life sciences, health, agronomy, environment. France $165 \mathrm{pp}$. (in French).

TAYLOR, B. R. - PARKINSON, D. - PARSONS, W. F. (1989): Nitrogen and lignin content as predictors of litter decay rates: a microcosm test. Ecology 70 (1): 97-104.

Toberman, H. - Evans, C.S. - FreEMAn, C. - Fenner, N. - White, M. - EMmetT, B.A. - ARTZ, R.R.E. (2008): Summer drought effects upon soil and litter extracellular phenol oxidase activity and soluble carbon release in an upland Calluna heathland. Soil Biology and Biochemistry 40 (6): $1519-1522$.

TRABAUD, L. (1976): Inflammabilité et combustibilité des principales espèces de la garrigue [Flammability and combustibility of the main species of the scrubland] CEcolgia Plant. 11: 117136. (in French).

Wieder, W. R. - Cleveland, C. C. - Townsend, A. R. (2009): Controls over leaf litter decomposition in wet tropical forests. Ecology 90(12): 3333-3341.

ZOUIDI, M. - BorSALI, A.H. - AlLAM, A. - GROS, R. (2018): Characterization of coniferous forest soils in the arid zone. Forestry Studies. Metsanduslikud Uurimused 68: 64-74. https://doi.org/10.2478/fsmu-2018-0006

Zouidi, M. - BorSALI, A. H., - KEFIFA, A. - Allam, A. - KEDDOURI, N. - GROS, R. (2019): Impact of the aridity gradient on the physico-chemical parameters of the needles of Pinus halepensis Mill. in the western Algeria. Indian Journal of Ecology 46 (1): 137-142. 